\title{
Balanced Scorecard: Strategy Towards World Class University
}

\author{
Rahman El Junusi \\ Universitas Islam Negeri (UIN) Walisongo Semarang \\ email: rahman_eljunusi@walisongo.ac.id
}

\section{Musahadi}

Universitas Islam Negeri (UIN) Walisongo Semarang

email: musahadi@walisongo.ac.id

\section{Heny Yuningrum \\ Universitas Islam Negeri (UIN) Walisongo Semarang email: henyyuningrum@walisongo.ac.id}

\begin{abstract}
The purpose of this research is how to implement the Balanced Scorecard (BSC) at UIN Walisongo in an effort towards world class university (WCU). The research design is policy research using explorative descriptive analysis techniques. The results show that in perspective (1) changes in research organizations: international collaborative research and international publications need to be improved, (2) human resource policies, increasing the number of professors and doctors and staff education, based on educational qualifications are still limited (3) academic programs, international accredited study programs need to be started, (4) Internal Governance, as an anticorruption campus that applies the best Integrity zone in PTKI and (5) Funds, develops and explores funding sources from domestic and foreign partners to strengthen the internationalization program towards WCU.
\end{abstract}

Keywords: World Class University; Balanced Scorecard; UIN Walisongo

\begin{abstract}
Abstrak: Tujuan penelitian adalah bagaimana implementasi BSC pada UIN Walisongo dalam upaya menuju world class university (WCU). Desain penelitian adalah penelitian kebijakan dengan menggunakan teknik analisis deskriptif eksploratif. Hasil penelitian menunjukkan bahwa dalam perspektif (1) perubahan organisasi: penelitian, masih terbatasnya penelitian kolaboratif internasional dan publikasi internasional, (2) kebijakan sumber daya manusia, meningkatkan jumlah profesor dan doktor dan pendidikan staf, berdasarkan kualifikasi pendidikan masih terbatas (3) program akademik, program studi terakreditasi internasional perlu dimulai, (4) Tata Kelola Internal, sebagai kampus anti-korupsi yang menerapkan zona Integritas terbaik di PTKI dan (5) Dana, mengembangkan dan mengeksplorasi sumber pendanaan dari mitra domestik dan asing untuk memperkuat program internasionalisasi menuju WCU.
\end{abstract}

Kata Kunci: World Class Universities; Balanced Scorecard; UIN Walisongo

Economica: Jurnal Ekonomi Islam - Volume 10, Nomor 1 (2019) 
Rahman El Junusi, Musahadi, Heny Yuningrum

\section{Introduction}

The term globalization is not a new phenomenon in the world view, as documented in "globalization a short history" (Niels P. Petersson and Jürgen Osterhammel 2009); (Stearns 2017); (Tohidfam, Baraghani, and Dalili 2016). According to Scholte, globalization is a process of universalization or a process that produces relationships and interconnections that transcend the boundaries of a country and society that form a modern world system (Scholte 2005). Globalization has driven and changed the world to become global because of the increasing interconnectedness and interdependence (Anthony Giddens, Patrick Diamond 2006). Globalization as "widening, deepening, and speeding up of interconnectedness in all aspects of contemporary life, from the cultural, to the criminal, the financial to the spiritual' (Meyer, Bushney, and Ukpere 2011).

Since globalization, education has become one of the service commodities (including the internationalization of education) has begun to penetrate higher education institutions in Indonesia. Globalization has transformed higher education institutions to improve quality and competitiveness towards world-class universities (P. G. Altbach and Knight 2007); (Morey 2004). Therefore, universities respond to globalization (P. G. A. Jamil Salmi 2016).

Globalization has different implications for higher education, but the growth and intensification of changes that occur in the global business environment also increase competition between universities, so they become competitors to offer quality higher education (Sudaryo 2015). Adopting the UNESCO program "World Declaration on Higher Education for the TwentyFirst Century: Vision and Action", the Directorate General of Higher Education (Dirjen Dikti) prepared a road map for higher education. In HELTS IV (2003-2010) that Indonesian people must prepare tertiary education to enter the global era, so that the term World Class University (WCU) is the 
ideals of higher education today, including Islamic tertiary institutions (PTKI).

The existence of Islamic education in the national context has an important role, especially as a foundation for developing Islamic education as a whole, therefore PTKI formulated its vision and mission by using academic quality as a guideline to achieve its goals (Ilyasin and Zamroni 2017). In the direction of the PTKI Strategic Plan (Renstra) that produces graduates who are Muslim and excel in integrating scholarships with Islamic values, the implementation of PTKI has reached 618 institutions, 53 in the form of PTKI State 565 Private PTKI in line with the demands of the globalization of higher education. Being a WCU is one way for PTKI to maintain its competitiveness at the international level. WCU can also be a medium to improve university performance in the fields of education, education and services for the community (Tri Dharma) which can be measured by the parameters of the Key Performance Indicators (IKU). The targets set in the KPI serve as parameters to measure the success of PTKI at the global level.

Table 1. PTKI Ranking Based on Webometric, QS and Times Higher Education (THE)

\begin{tabular}{llll}
\hline LEMBAGA & WEB & QS & THE \\
\hline UIN Syarif Hidayatullah & 4006 & not recorded & not recorded \\
\hline UIN Sunan Kalijaga & 4196 & not recorded & not recorded \\
\hline UIN Maulana Malik Ibrahim & 4430 & not recorded & not recorded \\
\hline UIN Sunan Ampel Surabaya & 4731 & not recorded & not recorded \\
\hline UIN Walisongo & 4406 & not recorded & not recorded \\
\hline UIN Alauddin & 5012 & not recorded & not recorded \\
\hline UIN Sunan Gunung Djati & 5583 & not recorded & not recorded \\
\hline
\end{tabular}

Source: processed data http://www.webometrics.info, http://www.qs.com; https://www.timeshighereducation.com 2018.

Economica: Jurnal Ekonomi Islam - Volume 10, Nomor 1 (2019) 
The internationalization of PTKI towards WCU to meet the demands of global quality international education is still far from expectations. According to QS and Times Higher Education and Webeometrics versions of the WCU ranking list in 2018, no PTKI is included in the WCU 500 ranking, explained in table 1.

UIN Walisongo is one of the PTKI institutions that strengthens the institution towards WCU as stated in the vision of "Excellence Research University Based on Knowledge Unity for Humanity and Civilization in 2038." The unity of science or also called the unity of science is the value of the university which is expected to become the University's identity. To achieve this vision and mission, it was revealed to be a strategy and this has been done through performance parameters consisting of: (1) increasing the distribution of PTKI access, (2) improving the quality of services at PTKI, (3) improving the quality of PTKI facilities and infrastructure, (4) increasing the quality and qualifications of PTKI educators and education personnel, (5) improving the quality of PTKI research / research results, (6) increasing the relevance and competitiveness of PTKI and (7) improving PTKI institutional management and autonomy.

However, IKU PTKI is expected to be unable to optimally increase PTKI competitiveness. So far, PTKI Performance Indicators have never been aligned with WCU assessment indicators and there are still many differences with WCU assessment criteria, so this has caused too many and inefficient indicators at IKU. In addition, according to the developed university performance model, it is still limited to the performance measurement model in which the development is concentrated on completeness. It is not yet known the extent of the validity of these performance indicators, both according to their content and construct. Because of this, a Balanced Scorecard (BSC) as a method of measuring and evaluating the performance of PTKI based on quality can be used as an operational and tactical strategy to get to WCU. 
BSC has been empirically practiced widely in business companies in Erapoa and Australia (Robert and Norton 1996). According to Nomura Research Institute (NRI) research, Japan has introduced BSC work patterns to more than 20 companies. And based on the experience of companies that apply performance measurement, BSC has advantages. BSC is a system that translates an organizations vision and mission that "balances financial and non-financial performance indicators including: customers, internal business processes as well as employee and organizational perspectives" (Kaplan and Norton 2001a). The BSC system is designed to win the competition in the global era where every university is demanded to have the ability to be able to win the competition (Niven 2005); (Sudaryo 2015).

Based on this reality, strategies and policies are needed to achieve WCU in accordance with the vision of the organization that focuses on improving academic quality. The researcher developed the concept of BSC as a tactical and operational performance measurement system used as a strategy to develop UIN Walisongo towards WCU (Kaplan and Norton 1992); (Robert and Norton 1996); (Intsiful and Maassen 2017); (P. G. A. Jamil Salmi 2016); (P. Altbach 2015); (N. C. L. Jamil Salmi 2011) develop in 5 (five) perspectives, including: (1) organizational change: research, (2) human resource policies, (3) academic programs, (4) internal governance ( governance) and (5) finance, which are integrated in a professional, transparent, accountable, quality organization and governance strategy management model and upholds the values of the mandate, tafaqquh fi al-din. Therefore the research objective is the implementation of BSC as a method of measuring and evaluating quality-based performance in an effort towards WCU.

\section{Literature Review}

\section{World Class University (WCU)}

According to Altbach WCU is a university that has a global ranking (P. G. Altbach 2004). WCU is a University that has an international reputation (Aula 
and Tienari 2011). Ramaprasad explaining that WCU is an Ecological institution with very different vision but very tightly integrated (Ramaprasad 2011). WCU is a university that has excellence in academic research and innovation (Nazarzadeh Zare et al. 2016). Salmi, J. \& Liu, N.C. states that WCU is given to universities that receive global recognition (N. C. L. Jamil Salmi 2011). While according to Hayes the world class dimension can be seen from research activities, publication excerpts, and awards from research institutions being the most significant measure of WCU (Hayes 2019).

Some researchers try to define what makes WCU different from others. "What does it mean to be a World Class University? Is this just a public relations claim or is there substance? What are the criteria for World Class status, and how do we know that a university has reached such a high altitude" (Henry M Levin, Jeong, Dong Wook, Ou 2006). "World-class universities can choose the best students and attract the most qualified professors and researchers" (P. G. A. Jamil Salmi 2016). "World-class universities have succeeded in mobilizing widely diverse national and international academic staff who tend to maximize the capacity of these institutions' knowledge networks" (N. C. L. Jamil Salmi 2011). Basically the characteristics of WCU indicate the existence of superior research quality in supporting the context of global higher education (P. G. Altbach 2004). According to Salmi collaborative between universities in the UK and China, shows that to get to WCU, universities must have an international reputation that contributes to the global community (Salmi 2009).

\section{Global University Ranking}

The idea of world-class universities (WCU) associated with global ranking in academic institutions (P. G. A. Jamil Salmi 2016); states that WCU refers to a ranking that has a standard of excellence globalization produced by universities (Huang 2012). In 2003 Shanghai University Jiao Tong published a ranking called "ARWU Academic World University" (N. C. L. Jamil 
Salmi 2011). Since then, QS has published a global, regional and national ranking system (Rauhvargers 2014). The global university ranking system uses a variety of very varied criteria (Tofallis 2012); (Rauhvargers 2011). ARWU is targeting 500 of the world's leading research universities, which qualify as WCU(P. G. A. Jamil Salmi 2016). THE-QS considers the university that is currently WCU. Therefore, it is not surprising THE-QS only chose around 600 WCU (Rauhvargers 2011).

Measurements and indicators have a big influence on the ranking results still cause debate from some researchers (Huang 2012). Criteria and indicators become differences in the order in which universities are listed in the global ranking; this raises questions about the validity and usefulness (Kaba 2012). Questions the validity of global rankings, based on the criteria used that do not represent the final results (Hou and Jacob 2017). In discussing differences with a better approach to global university ranking (Marginson 2014). Global ranking in tertiary education can provide comparative information and is a reality of the current world order, so global ranking has a major influence on WCU(Kaba 2012). There have been many hypotheses that the WCU idea currently rests on research excellence and publication (P. G. A. Jamil Salmi 2016). Of all the criteria and indicators of productivity research and publication the easiest way to measure WCU.

\section{Balanced Scorecard}

Balanced Scorecard is a measure of executive performance that requires a comprehensive measure with four perspectives, namely financial perspective, customer perspective, internal business perspective, and perspective growth and learning (Kaplan and Norton 1992); (Robert and Norton 1996). The Balanced Scorecard as: "a measurement and management system that views a business unit's performance from four perspectives: financial, customer, internal business process, and learning and growth" (Kaplan 2009) .The Balanced Scorecard (BSC) concept has been introduced 
by (Robert and Norton 1996), and implemented in many companies (Kaplan and Norton 2001b). This interest many researchers to apply BSC in nonprofit organizations and educational institutions (Niven 2005); (Pietrzak, Paliszkiewicz, and Klepacki 2015). In educational institutions BSC is used for quality management, so the philosophical principles of the balanced scorecard are used as dimensions of quality assurance in higher education (Reda 2017).

Initially, BSC was to improve the executive performance measurement system (Kaplan and Norton 1992); (Robert and Norton 1996). However, seeing a paradigm shift in the era of globalization, so that the BSC can use education systems and management to pursue WCU. Basically BSC implementation in higher education can be done based on studies from various aspects, and scorecard researchers in four perspectives according to the characteristics of higher education departing from the vision and mission. Researchers developed Intsiful and Maassen research entitled "Actors of Interpretation and Process of Organizational Change: Vision of the University of Ghana's Strategic Vision to Become a World-Class University" using 5 (five) perspectives, including: (1) organizational change: research, (2) organizational change: human resource policies (3) academic programs (4) organizational change: internal governance and (5) finance integrated in the management strategy model to achieve WCU (Intsiful and Maassen 2017).

\section{Implementation of the Balanced Scorecard in Higher Education}

In higher education institutions, BSC can be used as a tool to coordinate academic and non-academic activities (Küpper 2013). BSC can be used to improve the college's reporting process (Nayeri, Mashhadi, and Mohajeri 2008); (Umashankar and Dutta 2007). In much literature, the BSC model is implemented in higher education (Taylor and Baines 2012); (Papenhausen and Einstein 2006). In recent years universities in the UK have increasingly been concerned with performance management, BSC is used as a means to 
improve institutional performance (Taylor and Baines 2012). Successful BSC implementation requires the active role of all organizational components (Papenhausen and Einstein 2006).

Based on previous research, researchers developed the BSC model from (Kaplan and Norton 1992); (Robert and Norton 1996); (Intsiful and Maassen 2017); (P. G. A. Jamil Salmi 2016), (P. Altbach 2015); (Taylor and Baines 2012) based on 5 (five) perspectives, among others: (1) organizational changes: research, (2) organizational changes: human resource policies (3) academic programs (4) organizational changes: internal governance and (5) finance integrated in a UIN strategy model Walisongo to get to WCU. To analyze the implementation of the BSC, the Indicator used serves as a measure to analyze whether changes are occurring, among other things (1) organizational changes: research that aims to strengthen research activities including: grant research funding or collaborative research and publication. (2) organizational changes: human resource policies indicators used include changes in recruitment procedures, changes in HR criteria and reward or incident systems. (3) academic programs, indicators used are master / doctor programs, curriculum system changes and academic internationalization programs (4) organizational changes: internal governance, indicators used are changes in decision making, changes in organizational structure, changes in work culture and (5) Finance, with indicators for increasing budgeting in research, human resources, academic programs and internal governance. In other words, indicators can be formulated as a strategy towards WCU. 
Rahman El Junusi, Musahadi, Heny Yuningrum

Figure 1. Theoretical Framework

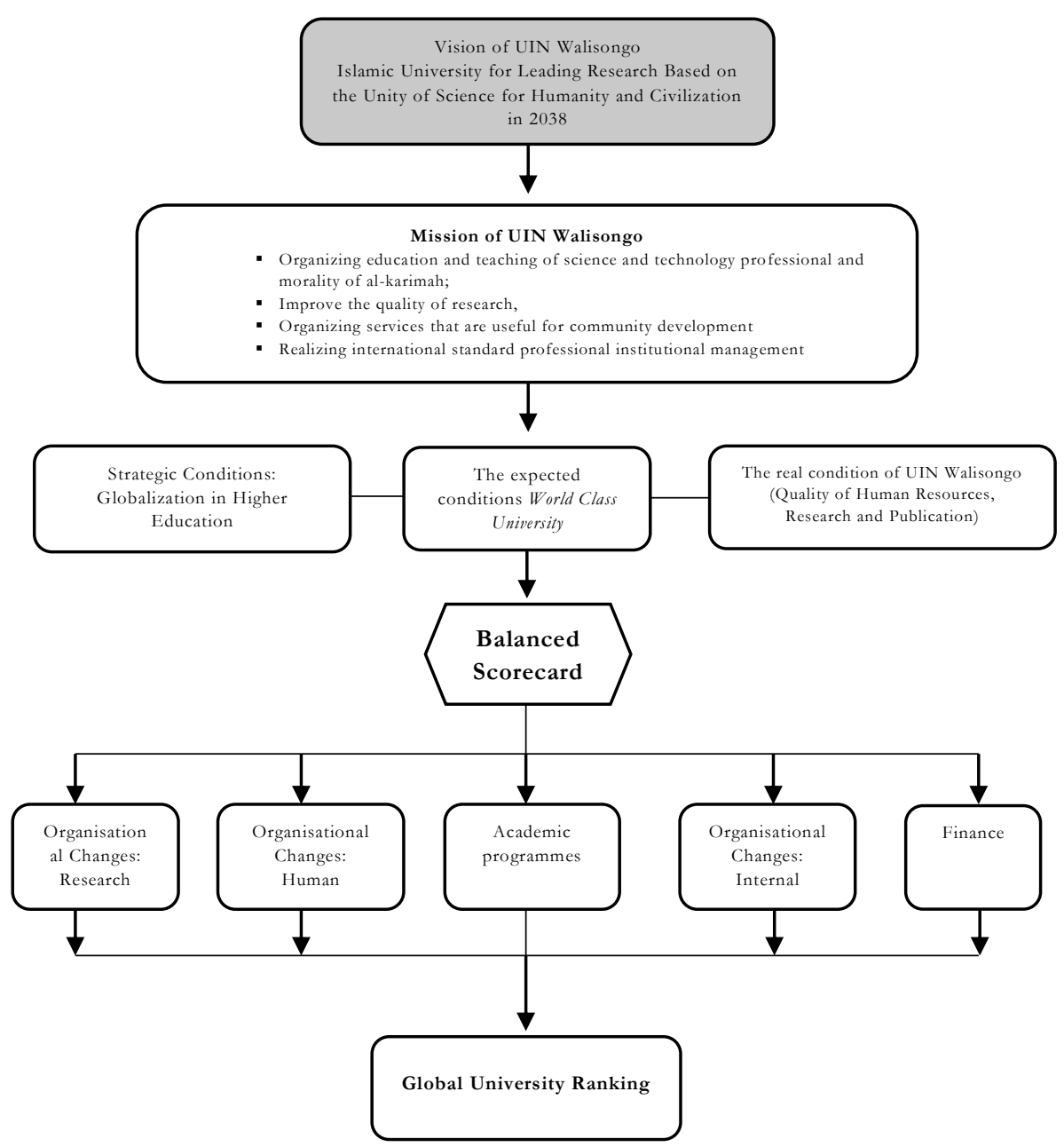

\section{Methods}

This research is a policy research. In addition this research, based on interpretative paradigms, is associated with qualitative processes such as phenomenology and the tradition of case studies (Yin 2013). Data collected 
in the context of case studies are studied as an integrated whole aimed at developing in-depth knowledge of existing research subjects. Thus this case study can also be called explorative research (Moleong 2012). Therefore, this research design uses a case study approach namely how the UIN Walisongo strategy towards WCU with the BSC strategy approach.

Data sources are focused on those who are directly involved in making policies and units that handle research, scientific publications, so they can provide information about strategies towards WCU. Interviews addressed to informants included: Muhibbin as rector, Musahadi as Deputy Rector I, Muhyar Fanani as dean of Social Sciences, Muhayya as chairman of LPM, Solichan as chair of LP2M, Syamsul Maarif as head of research center at LP2M, Nur Faizah as head of the Organization and Personnel Section, and Lu'luatil as a BLU driver. The data analysis is inductive analytic, which emphasizes the meaning of the specificity of a case that is grounded in the logic of positivism and phenomenology, Therefore the data analysis technique used is descriptive exploratory.

\section{Results and Discussion}

\section{Organizational Changes Research Perspective}

In the perspective of organizational changes: research, according to Intsiful and Maassen (2017) in the table 2.

Table 2. Perspektif Organisational Changes: Research

\begin{tabular}{ll}
\hline Organisational Changes: Research & Indicator \\
\hline & Research grants / funding \\
\hline Collaboration \\
\hline Publication \\
\hline
\end{tabular}

Source: developed from (Intsiful and Maassen 2017)

Economica: Jurnal Ekonomi Islam - Volume 10, Nomor 1 (2019)

http://journal.walisongo.ac.id/index.php/economica 
According to Solichan "In terms of research funding, UIN Walisongo experienced a significant increase, for example there was Rp. 15 million, Rp. 40 million, and even up to Rp. 200 million. "Hopefully we have awareness, during this time with mediocre funds that can make intellectual leaps, publications and indexed everywhere. That means a spirit of extraordinary enthusiasm, especially with the current budget or not, there must be a policy of research sense. To collaborative research in 3 years. Lots of collaboration in Australia, Singapore, Malaysia, Thailand, America."

Meanwhile, according to Syamsul Maarif "with the increasing research funding, UIN Walisongo is able to facilitate the amount of research and publishing assistance delivered by lecturers which continues to increase from year to year. In addition, increased funding also allows conducting joint research activities between UIN Walisongo research lecturers and academic partners of world universities. By building a network that is very important to undergo a network, increasing funds to solve the problems of the nation state, intelligent and have an extraordinary impact. Culture, building networks and creating programs creatively, I think the impact will be felt not only by building programs, but also established networks. "

In terms of publication, in the National Journal of National Accreditation Walisongo UIN in 2018 there were 22 journals in which the average journal was published twice a year. National accredited journals are 5 journals or $22 \%$ of available journals while there are no international journals. The number of articles published, especially journals scopus indexed is still low, according to IKU, there were 7 international journals in 2017 that have been exceeded. However, judging from the number and quality of writing articles owned by the lecturer it still needs to be improved, because many lecturers can write articles, but only for the sake of promotion, not published, especially at the international level or indexed scopus. 


\section{Human Resource Policies Perspective}

In the perspective of human resource policies, the indicators used in the following table:

Table 3. Human Resource Policies Perspektif

\begin{tabular}{ll}
\hline Human Resources Policy & Indicator \\
\hline & Changes to recruitment procedures \\
& Reward / Incentive System \\
\hline
\end{tabular}

Source: developed from (Intsiful and Maassen 2017)

In the perspective of human resource policies, performance achievements of UIN Walisongo HRD can be measured from the qualifications of lecturers and education personnel. For lecturers, there are 114 or $23 \%$ of lecturers having S3 degrees while 386 or $77 \%$ of lecturers have S2 degrees, while 20 lecturers or $4 \%$ lecturers have professors. For the qualifications of educational staff, there are 28 people or $10 \%$ have S2 education, 181 people or $62 \%$ have S1 education, 6 people or $2 \%$ have DIII education and 79 people or $27 \%$ have high school education. Seeing the achievement of HR performance, the qualifications of lecturers and teaching staff of UIN Walisongo need to be improved with policies that can accelerate the improvement of lecturer qualifications in the framework of WCU.

Muhibbin stated that "To develop research and publication activities of UIN Walisongo, it is based on: Effective and quality recruitment of human resources. Increasing the effectiveness and quality of recruitment of employee and lecturer resources is intended to get professional and highly dedicated human resources. The goal of increasing the effectiveness and quality of recruitment is carried out with a structured, measured, planned, and systematic program. recruitment is based on competence. The form of 
the program to achieve this goal are: (1) employee and lecturer recruitment systems based on needs and competencies; (2) open recruitment system; and 3) high qualification requirements for interested people. Whereas the reward system at UIN Walisongo uses remuneration, which is a more objective and fair system of providing income or payroll to employees. Remuneration applied in government institutions is sourced from Pure Rupiah (RM) funds, which are also known as APBN (State Budget) funds and / or sourced from Non-Tax State Revenue (PNBP) funds or commonly referred to from BLU funds. Remuneration consists of salary, honorarium and performance incentives (KMK 1178 2015). When viewed from the remuneration element, the payroll system becomes simpler and leads to performance-based payroll. Salary is paid with due regard to group, position value, responsibilities and / or years of service. Honororarium is given to the BLU Supervisory Board which is sourced from PNBP funds. Performance incentives are given to management officials / employees sourced from PNBP funds based on the Key Performance Indicator (KPI) achievements set in the performance contract."

\section{Academic Program Perspective}

UIN Walisongo has 7 master programs, namely: Islamic Religion, Falak Science, Qur'anic Studies and Interpretation; Islamic Economics, Islamic Religious Education, Islamic Education Management, Islamic Communication and Broadcasting, and 1 doctoral program namely Islamic studies. According to Muhaya "curriculum development, the paradigm developed is that all knowledge is basically a unity that originates from and empties into God through His revelation both directly and indirectly. With the concept of scientific building the integration of science developed is based on a paradigm called wahdat al-ulum (unity of science). This paradigm asserts that all knowledge is basically a unity that originates from and empties into God through His revelation both directly and indirectly. Therefore, all knowledge 
should have mutual dialogue and lead to one goal, namely to deliver the study to know and be closer to God as al-alim (the all-knowing). The curriculum policy was developed based on the unity of science paradigm of integration based on science. While the strategy of implementing scientific integration in curriculum development, incorporating religious values into the curriculum and RPS (Semester Learning Plan) Coaching New lecturers to develop the competence of unity of science making the template for developing a unity of scince RPS development." Indicators in the Academic Program Perspective in the following table 4 :

Table 4. Academic Programmes Perspektive

\begin{tabular}{ll}
\hline Academic program & Indicator \\
\hline & Master / Doctoral Program \\
\hline Curriculum Development \\
\hline International Program \\
\hline
\end{tabular}

Source: developed from (Intsiful and Maassen 2017)

Meanwhile, according to Musahadi "The Walisongo UIN International Program is mostly carried out by the 4 in 1 program. The Support for Quality Improvement of Islamic Higher Education Project is a collaborative project between the Islamic Development Bank and Walisongo UIN which has been implemented since 2013. There are several programs carried out including: (1) Non degree training - overseas: overseas training in various disciplines relevant to the needs of UIN Walisongo. During the program, there were 19 overseas training courses with 268 lecturers and employees; (2) Visiting professors are programs specifically for teachers, there are 11 professors participating in this program; (3) Doctoral Research Program and Post- 
doctoral Program are overseas research assistance programs provided to UIN Walisongo lecturers who are studying doctoral programs and are completing doctors who have been attended by 54 people; (4) Comparative study - overseas: This program is intended for lecturers and student leaders who aim to broaden their scientific insights and expertise, increase competitiveness and establish and strengthen partnerships and cooperation at the international level. During the program 18 programs were participated in by 73 lecturers, staff and students; (5) Opening of the International Class Program, Study Program of Religions (SAA Study Program) in an effort to make UIN Walisongo able to compete at the Asia and World level. From the scientific approach, SAA study program uses a multi and interdisciplinary approach in line with the vision and mission of UIN Walisongo which is based on the paradigm of "unity of sciences" or wahdatul ulum); (6) Joint research or collaborative research through competition for grant funds with universities of international repute; (7) Guest lectures and lecturers exchange and (8) Joint international conferences international conferences which are carried out in collaboration with domestic and foreign universities."

\section{Internal Governance Perspective}

In the perspective of Internal Governance, UIN Walisongo is a university with a legal entity Public Service Agency (BLU). According to PP N0. 23 Tahun 2005 "BLU is an institution within the Government that was formed to provide services to the community in the form of the supply of goods and / or services sold without prioritizing profit seeking and in carrying out its activities based on the principles of efficiency and productivity. While the Public Service Agency Financial Management Pattern, hereinafter referred to as PPK-BLU, is a financial management pattern that provides flexibility in the form of flexibility to implement sound business practices to improve services to the public in order 
to advance public welfare and improve the life of the nation." The indicators used in the Internal Governance Perspective are as follows table 5:

Table 5. Internal Governance Perspective

\begin{tabular}{ll}
\hline Internal Governance & Indicator \\
\hline & Changes in Higher Education Institutions \\
\cline { 2 - 2 } & Changes in organizational structure \\
\hline
\end{tabular}

Source: developed from (Intsiful and Maassen 2017)

According to Muhibbin, "Since 2009, UIN Walisongo was originally a satker work unit becoming a BLU through Minister of Finance Decree No. 68 / KMK.05 / 2009 concerning Amendment to the Establishment of the Walisongo State Islamic Institute of Semarang in the Department of Religion as a Government Agency Implementing the Financial Management Pattern of Public Service Agencies. Based on Changes in Higher Education into BLU bodies, There are 4 aspects that are emphasized, namely: leadership, learning (teaching), research (research), and supporting staff. Institutionally related to the reputation and image of UIN Walisongo, the public is increasingly trusted. National and international collaboration is based on higher education management systems in a professional, accountable and transparent manner. This foundation continues to be strengthened in the management of healthy and good tertiary institutions, to create a management system according to the needs and to have resilience in following the challenges of the times."

The development of healthy tertiary institutions is based on the application of good university governance (GUG), so UIN Walisongo has declared a campus of corruption-free territory since January 3, 2012. Until now UIN Walisongo holds a commitment as a campus free of corruption. 
Rahman El Junusi, Musahadi, Heny Yuningrum

According to Muhibbin "I require all UIN Walisongo officials not to receive gratuities from partners or winners of development project tenders. This is done so that the campus is clean and free of bribery and corruption. I returned all holiday parcels given by partners, this is to keep from gratification. In addition, UIN Walisongo is designated as a university that implements the best integrity zone within PTKI. The Integrity Zone must be able to build accountability that can be trusted by the community. That zone of integrity means that supervision is not only from the leadership, but it starts with oneself. Actions that are carried out with integrity, both justified in religion and applicable regulations. The most fundamental essence in the integrity zone is that supervision is on each individual and becomes a daily belief or deed. Management in aspects of management, organizational governance, and human resources. They all must have the same commitment to carry out their mandate with integrity. According to Muhibbin, there is no such thing as doing good when there is only a leader. Or do no good when there is no leader. Integrity zones must have clear operational standard procedures for every program implementation".

The Integrity Zone is carried out by the Integrity Zone development Team consisting of 40 people from various units. The inauguration was held at the launch of UIN to become an Integrity Zone (ZI) campus towards the Corruption Free Region (WBK) campus, as well as the Clean and Servicing Bureaucracy Region (WBBM). Faizah said that, "Later the team that will prepare the items that have to be fulfilled will go to a corruption-free university of integrity. There are at least six items that must be fulfilled. Among other things, change, accountability, readiness to provide excellent service, and other items. After being prepared, an in-depth evaluation will be carried out by the relevant institutions, both from the Men-PAN, Ombusdman, and even the KPK."

In order to realize good HR governance for employees or lecturers, UIN Walisongo has Launched SKP Online Compilation of Position Analysis and 
Performance Load Analysis. The compilation of job analysis and workload analysis and information on job factors in the UIN Walisongo environment are in accordance with the theory of good governance where the pattern of governance is very in line with the institution's strategic goals. Faizah stated that "We have a target, our campus is a period of efficiency, the goal is to build good governance. After this governance goes well, we will improve its main performance", SKP Online is one form of performance evaluation of education staff in performing their tasks. Online SKP can be done on the website skp.walisongo.ac.id Procurement of this application has the support of various parties, both from the faculty, staff and students.

In realizing transparency and accountability, in the fields of planning and finance, UIN Walisongo has launched the Budget Realization Information System (SIRA) application. Budget Realization Information System is an application that was built to meet the needs of the work unit for an application that is able to become a tool in the implementation of management and supervision of state finances that are efficient, effective, reliable and user friendly. This system has 5 sub-systems including administrators, operators, official travel, treasury bookkeeping and treasurer expenditure accounting records.

Lu'luatil states that "The information system used in the planning and financial department is SIRA (Budget Realization Information System). The purpose of this SIRA is to be more controlled in budgeting. Back when I was still using Ms. Our Excel can't monitor budgeting. This SIRA adopts from the central education center, but not all winners use SIRA. All components in the SPJ can be made through SIRA. The user, for my own admin, the leader to monitor the realization of the budget of each faculty and center, operators per faculty unit also exist, BPP users to issue SPP and SPM. This software is customization, meaning that SIRA still needs development according to the needs that we want. This SIRA monitors how much realization, what percentage to pursue or accelerate disbursement so that each faculty 
matches the disbursement schedule matrix. There are discrepancies that occur usually when they have long input but have not been thawed. It all depends on them, but when we monitor because it has been inputted, sometimes it is already included in the realization. So there is a difference between the realization that has been completely liquid with the newly inputted. When it becomes SPP, it usually reaches here, but sometimes when it becomes SPP, the file is still in SPI or the operator still holds it. However, because it has been inputted at SIRA there is usually a GAP of about one week. So, there is a different realization from the real disbursement. In the future, to improve the quality of SIRA, there will be training for HR and the development of SIRA itself. Besides that, SIRA is used for monitoring related to budget realization, which is used as a budget absorption strategy".

The second indicator of governance is organizational change from work units (Satker) to BLU. In Law No. 12 Tahun 2012 Article 65 and PP No. 4 Tahun 2014 Article 27 Dividing PTN Management Patterns, namely as work units subject to the Ministry of Education and Culture, public service bodies (BLU), or PTN Legal Entities (PTN BH). The consequence of the change in institutional status has an impact on changes in the types of lecturers, the recruitment system of lecturers and education staff, the remuneration system of lecturers and researchers, the management of research and the organizational structure contained in the statute, therefore in line with the main tasks and functions in the field of higher education in realizing world class university and global recognition, a new organization was formed to carry out the task of establishing international service cooperation for the academic community.

The international office was established to fully support the vision and mission of UIN Walisongo, one of the dreams of being part of the international academic community. The position of the technical implementation unit (UPT) under the Vice Chancellor of Student Alumni and cooperation, its main task is to expand the network, bring students and 
lecturers from abroad and promote UIN campus abroad. Therefore the international office which is a new institution functions to support the achievement of UIN vision Walisongo headed to WCU.

\section{Finance Perspektive}

To build WCU, it requires financial and non-financial support. Nonfinancial support includes quality research results, student achievements, and others. Whereas for financial support, funds from sources of income from student education costs are needed, profits from ventures, profits from existing research results, funding through the state budget, private sector donations and the role of institutions. The budget for Walisongo State Islamic University is sourced from: Pure Rupiah (RM), Complementary Pure Rupiah (RMP), BLU, Grants and Cooperation as well as PLN Luara State Loans, budgets originating from BLU are explained in table 6 .

Table 6. UIN Walisongo Budget 2015-2018 (in Millions of Rupiah)

\begin{tabular}{lrrrr}
\hline Information & $\mathbf{2 0 1 5}$ & $\mathbf{2 0 1 6}$ & $\mathbf{2 0 1 7}$ & $\mathbf{2 0 1 8}$ \\
\hline RM & 135,703 & 106,316 & 117,637 & 129,475 \\
\hline RMP & 14,880 & 13,423 & - & - \\
\hline BLU & 28,843 & 35,056 & 40,644 & 54,518 \\
\hline PLN & 14,616 & - & 24,385 & 88,751 \\
\hline Total & $\mathbf{1 9 4 , 0 4 3}$ & $\mathbf{1 7 7 , 8 3 0}$ & $\mathbf{1 8 2 , 6 6 7}$ & $\mathbf{2 7 2 , 7 4 4}$ \\
\hline
\end{tabular}

From table 6 shows that, UIN Walisongo budget fluctuated, in 20152016 decreased 8.35\%, while in 2016-2018 it increased 4.93\%. Based on the allocations set out in the 2015-2019 RPJMN, the 2015-2019 Islamic Education funding framework derived from APBN funding sources is IDR 127 trillion, and IDR 4,904 trillion is allocated to improve PTKI quality. So the average budget of Walisongo State Islamic University is only $5.56 \%$ of all 
PTKI members. With a limited budget, UIN Walisongo is required to improve academic quality and be able to compete at the international level in the context of going to WCU. Because there needs to be a strategy to increase education funding, including: increasing BLU funding through: optimization of assets (use of Halls, Halls, Mahad, polyclinics, GSG, Canteens, reporters, libraries and other potential assets); developing new business units (Tour \& Travel, Ticketing, Hajj and Umrah, Snack and Catering, Walisongo Press publishing and printing, Walisongo Water) and increasing cooperation with domestic and foreign partners

Altbach states that "Charles W. Eliot, president of Harvard for nearly 40 years at the end of the 19th century, when asked by John D. Rockefeller what was needed to create the equivalent of a world-class university, replied that it would need \$ 50 million and 200 years. He is wrong. At the beginning of the 20th century, the University of Chicago became a world-class institution in two decades and a little more than $\$ 50$ million was donated at the time by Rockefeller himself. Prices have jumped, not only because of inflation but because academic institutions have become much more complex and expensive. Competition is also becoming increasingly fierce. Now, it may take more than $\$ 500$ million" (P. G. Altbach 2004).

In line with Musahadi that, "as is the case with UIN Walisongo, the activities carried out to get to WCU are still based on government sources. In addition, they received financial assistance from IsDB which was used for programs towards WCU through the The Support to Quality Improvement of the Islamic Higher Education project funded by IsDB. The scope of the project covers: (1) improving access: construction of 8 new buildings (developing lecture halls, modern laboratories, planetariums, modern libraries and central administration), supporting infrastructure development, furniture / fixture procurement, (2) quality improvement: curriculum development, management, overseas training, student affairs and IT Development" . In general, the program shows encouraging results, the webeometric version of 
UIN Walisongo including the top five WCU ranks among PTKI and the accreditation of tertiary institutions (AIPT) gets an A by BAN-PT.

\section{Conclusion}

Based on the discussion, it can be concluded that the measurement of Walisongo UIN performance with the BSC approach in the strategy effort towards WCU is as follows: (1) Organizational perspective changes: research. Demonstrated increasing variation in research and international collaborative research. In 2016 there were 2 collaborative studies and in 2018 it increased to 8 collaborative studies. Likewise regarding publications, there are $22 \%$ of journals that have been nationally accredited, but there are no international journals. While the publications of lecturers writing in international journals, are still limited even though the Main Performance Index (IKU) has been exceeded, namely 7 international journals that are scopus indexed. So in the perspective of organizational changes: international collaborative research studies and international publications need to be improved in the context of WCU.

(2) Perspective of human resource policies. Of the 500 lecturers there are 20 professors or $4 \%$ while lecturers hold doctoral degrees $23 \%$ or 100 lecturers. Ideally to be a high quality university with a minimum of 40 percent of the total number of professors, this is because one of the benchmarks for WCU ranking is that at least 40 percent of professors are in higher education, with the diversity of these conditions a challenge for UIN Walisongo in continuing to do an accelerated program of internationalization towards WCU. So in the perspective of human resource policies, it is necessary to increase the number of lecturers holding professors and doctoral degrees, through the policy of accelerating the development of lecturer quality, so that lecturers can be fast doctors, the doctors must be fast professors. In addition, UIN Walisongo must have a special program so that there will be doctor acceleration to professor acceleration.

Economica: Jurnal Ekonomi Islam - Volume 10, Nomor 1 (2019) 
(3) Academic program perspective. The UIN Walisongo International Program is mostly carried out by 4 in 1 "The Support for Quality Improvement of Islamic Higher Education Project" is a collaborative project between the Islamic Development Bank and UIN Walisongo with a variety of program activities including: Non-degree training-overseas, Visiting professors, Doctoral Research Program, Post-doctoral Program, Comparative study-overseas, Opening of International Class Program, Joint research or collaborative research, Guest lecturing and lecturers exchange, Joint international conference and scholarship program for doctor. In addition, more than $20 \%$ of study programs have been accredited by A BAN-PT. In the perspective of academic programs, internationalization programs vary greatly, but need to be maintained and developed. To continue to exist and be able to compete in the global world, it is necessary to start an internationally accredited study program, because there are no internationally accredited study programs. Therefore, UIN Walisongo began to organize itself through preparation, innovative strategies towards WCU and contributing to solving global problems.

(4) Internal Governance Perspectives. Since 2009, UIN Walisongo has become a BLU from an ordinary satker, and in 2015 transformed itself from IAIN to UIN Walisongo, resulting in changes in the organizational structure contained in the statute. In addition, UIN Walisongo declared it to be a campus of corruption-free territory, and in 2018 it was established as a university that implements the best integrity zone in the PTKI environment so that it can build public accountability and trust. In the Internal Governance Perspective, it is the perspective that is most ready for UIN Walisongo towards WCU.

(5) Finance perspective. The Walisongo UIN budget has on average increased, particularly in the presence of foreign loans from the Islamic Development Bank through the 4 in 1 program The Support to Quality Improvement of the Islamic Higher Education Project, which is used to 
develop quality improvement and internationalization programs in order to realize WCU. In the financial perspective, UIN Walisongo needs to develop and explore sources of funding. So far, most of the funding from the government and foreign loans, so that the necessary expansion and cooperation through the tri dharma program of higher education both with domestic and foreign partners in strengthening the funding of internationalization programs towards WCU.

This study has several limitations including: a study conducted at 1 PTKI institution, namely UIN Walisongo, so the results cannot be generalized. In addition, the perspectives used by researchers in the BSC are modified from Kaplan, R.S. \& Norton, D.P. (1996). BSC theory, which is not yet known how much its relationship with WCU. Therefore, for the future research agenda, the BSC model needs to be applied to several PTKI institutions and be compiled so that a more comprehensive picture of the BSC as a parameter of PTKI's performance in the effort to go to WCU is needed, so it is necessary to add stakeholder perspectives in future research models.

\section{References}

Altbach, Philip. 2015. "India: World-Class Universities?" International Higher Education, no. 40: 5-8. https://doi.org/10.6017/ihe.2005.40.7484.

Altbach, Philip G. 2004. "The Costs and Benefits of World-Class Universities." Academe 90 (1): 20-23. https://doi.org/10.2307/40252583.

Altbach, Philip G., and Jane Knight. 2007. "The Internationalization of Higher Education: Motivations and Realities." Journal of Studies in International Education 11 (3-4): 290-305. https://doi.org/10.1177/1028315307303542.

Anthony Giddens, Patrick Diamond, Rogger Liddle. 2006. "Global Europe, Social Europe." Malden, USA: Polity Press.

Aula, Hanna Mari, and Janne Tienari. 2011. "Becoming 'World-Class'? Reputation-Building in a University Merger." Critical Perspectives on 
Rahman El Junusi, Musahadi, Heny Yuningrum

$\begin{array}{llll}\text { International } & \text { Business } & 7 & \text { (1): }\end{array}$ https://doi.org/10.1108/17422041111103813.

Hayes, Aneta. 2019. "We Loved It Because We Felt That We Existed There in the Classroom!': International Students as Epistemic Equals Versus Double-Country Oppression." Journal of Studies in International Education. https://doi.org/10.1177/1028315319826304.

Henry M Levin, Jeong, Dong Wook, Ou, Dongsury M. 2006. "WHAT IS A WORLD CLASS UNIVERSITY." Paper Presented at The Conference Of The Comparative and International Education Society. Hawai.

Hou, Ya Wen, and W. James Jacob. 2017. "What Contributes More to the Ranking of Higher Education Institutions? A Comparison of Three World University Rankings." International Education Journal 16 (4): 29-46.

Huang, Mu Hsuan. 2012. "Opening the Black Box of QS World University Rankings." Research Evaluation 21 (1): 71-78. https://doi.org/10.1093/reseval/rvr003.

Ilyasin, Mukhammad, and Zamroni Zamroni. 2017. "Balanced Scorecard: A Strategy for the Quality Improvement of Islamic Higher Education." Dinamika Ilmu 17 (2): 223-36. https://doi.org/10.21093/di.v17i2.703.

Intsiful, Emmanuel, and Peter Maassen. 2017. "Actors' Interpretations and Organisational Change Processes: The Case of the University of Ghana's Strategic Vision of Becoming a "World Class University." Journal of Education and Practice 8 (5): 1-11.

Jamil Salmi, Nian Cai Liu. 2011. "Paths to a World-Class University." In Paths to a World-Class University. Rotterdam/Boston/Taipei: Sense Publisher. https://doi.org/10.1007/978-94-6091-355-6.

Jamil Salmi, Philip G. Altbach. 2016. "Encyclopedia of International Higher Education Systems and Institutions." Encyclopedia of International Higher Education Systems and Institutions, 1-7. https://doi.org/10.1007/978-94-017-9553-1.

Kaba, Amadu Jacky. 2012. "Analyzing the Anglo-American Hegemony in the Times Higher Education Rankings." Education Policy Analysis Archives 20: 21. https://doi.org/10.14507/epaa.v20n21.2012.

Kaplan, Robert S. 2009. "Conceptual Foundations of the Balanced Scorecard." Handbooks of Management Accounting Research 3: 1253-69. https://doi.org/10.1016/S1751-3243(07)03003-9. 
Kaplan, Robert S., and David P. Norton. 1992. "The-Balanced-Scorecadr." Harvard Business Review.

- - - 2001a. "Transforming the Balanced Scorecard from Performance Measurement to Strategic Management: Part I." Accounting Horizons 15 (1): 87-104.

Kaplan, Robert S, and David P Norton. 2001b. "Transforming the Balanced Scorecard from Performance Measurement to Strategic Management: Part II." Accounting Horizons 15 (2): 147-60.

Küpper, Hans Ulrich. 2013. "A Specific Accounting Approach for Public Universities." Journal of Business Economics 83 (7): 805-29. https://doi.org/10.1007/s11573-013-0682-4.

Marginson, Simon. 2014. "University Rankings and Social Science." European Journal of Education 49 (1): 45-59. https://doi.org/10.1111/ejed.12061.

Meyer, Marius, Melanie Bushney, and Wilfred Ukpere. 2011. "The Impact of Globalisation on Higher Education: Achieving a Balance between Local and Global Needs and Realities." African Journal of Business Management 5 (15): 6569-78. https://doi.org/10.5897/AJBM11.205.

Moleong, Lexy J. 2012. "Metodologi Penelitian Kualitatif." Bandung: Remaja Rosdakarya.

Morey, Ann I. 2004. "Globalization and the Emergence of For-Profit Higher Education." Higher Education 48 (1): 131-50. https://doi.org/10.1023/B:HIGH.0000033768.76084.a0.

Nayeri, M D, M M Mashhadi, and K Mohajeri. 2008. "Universities Strategic Evaluation Using Balanced Scorecard." World Academy of Science, Engineering and Technology, no. 37: 332-37.

Nazarzadeh Zare, Mohsen, Javad Pourkarimi, Gholamreza Zaker Salehi, and Sahba Rezaeian. 2016. "In Search of a World-Class University in Iran." Journal of Applied Research in Higher Education 8 (4): 522-39. https://doi.org/10.1108/JARHE-03-2016-0021.

Niels P. Petersson, and Jürgen Osterhammel. 2009. "Globalization: A Short History - Jürgen Osterhammel, Niels P. Petersson - Google Books." Ney Jersey: Princeton University Press. 
Rahman El Junusi, Musahadi, Heny Yuningrum

Niven, Paul R. 2005. "Driving Focus and Alignment With the Balanced Scorecard." Journal for Quality \& Participation 28 (4): 21-25.

Papenhausen, Chris, and Walter Einstein. 2006. "Implementing the Balanced Scorecard at a College of Business." Measuring Business Excellence 10 (3): 15-22. https://doi.org/10.1108/13683040610685757.

Pietrzak, Michał, Joanna Paliszkiewicz, and Bogdan Klepacki. 2015. "The Application of the Balanced Scorecard (BSC) in the Higher Education Setting of a Polish University." Online Journal of Applied Knowledge Management 3 (1): 151-64.

Ramaprasad, Arkalgud. 2011. "Envisioning a World-Class University System for India." International Journal of Technology Management \& Sustainable Development. $\quad$ Vol. 10. https://doi.org/10.1386/tmsd.10.1.45_1.

Rauhvargers, Andrejs. 2011. "Achieving Bologna Goals: Where Does Europe Stand Ahead of 2010." Journal of Studies in International Education 15 (1): 4-24. https://doi.org/10.1177/1028315310373834.

- - - 2014. "Where Are the Global Rankings Leading Us? An Analysis of Recent Methodological Changes and New Developments." European Journal of Education 49 (1): 29-44. https://doi.org/10.1111/ejed.12066.

Reda, Nigusse Weldemariam. 2017. "Balanced Scorecard in Higher Education Institutions: Congruence and Roles to Quality Assurance Practices." Quality Assurance in Education 4 (3): 7-8. https://doi.org/10.1108/mbe.2000.26704caa.006.

Robert, David Kaplan, and Norton. 1996. "Linking the Balanced Scorecard to Strategy." California Managment Review 39 (1): 53-79.

Salmi, Jamil. 2009. The Challenge of Establishing World-Class Universities: Executive Summary. The World Bank. Vol. 53. Washington DC: The Word Bank. https://doi.org/10.1093/cid/cir625.

Scholte, Jan Aarte. 2005. "Globalization: A Critical Introduction - Jan Aart Scholte - Google Books." London: Red Globe Press.

Stearns, Peter N. 2017. GLOBALIZATION IN WORLD HISTORY. New York And London: Routledge. 
Sudaryo, Yoyo. 2015. "Kinerja Perguruan Tinggi Dengan Pendekatan." Sosiohumaniora 17 (1): 1-12.

Taylor, John, and Claire Baines. 2012. "Performance Management in UK Universities: Implementing the Balanced Scorecard." Journal of Higher Education Policy and Management 34 (2): 111-24. https://doi.org/10.1080/1360080X.2012.662737.

Tofallis, Chris. 2012. "A Different Approach to University Rankings." Higher Education 63 (1): 1-18. https://doi.org/10.1007/s10734-011-9417-z.

Tohidfam, Mohammad, Maryam Khosravi Baraghani, and Shahab Dalili. 2016. "Identity, the Main Term of Contrast between 'Globalization' and 'Universalization'-An Interpretention with a Critical Linguistic Approach" 6 (3): 155-61. https://doi.org/10.17265/21595313/2016.03.005.

Umashankar, Venkatesh, and Kirti Dutta. 2007. "Balanced Scorecards in Managing Higher Education Institutions: An Indian Perspective." International Journal of Educational Management 21 (1): 54-67. https://doi.org/10.1108/09513540710716821.

Yin, Robert K. 2013. "Validity and Generalization in Future Case Study Evaluations." $\quad$ Evaluation 19 (3): $\quad 321-32$. https://doi.org/10.1177/1356389013497081. 
